\title{
O nome de Deus
}

\author{
Paulo Abe
}

Abraham era um judeu ortodoxo de Jerusalém, um dos tantos haredim na Terra Santa. E como todos, ele também era pago pelo governo para estudar a Torá e fazer novas descobertas sobre as sagradas escrituras e a língua hebraica. Esse era o trabalho de todos dessa elite do profundo saber de Deus, a Cabala. Inúmeros livros e manuscritos ele possuía em sua casa, como todos os volumes do Zohar, da Torá, dos Neviim, dos Kethuvim, e outros tantos livros em sua biblioteca privada, seu grande orgulho.

Como um bom escolástico, estudava sempre em grupo na sinagoga e até ia aos encontros semanais no segundo andar de uma velha livraria na rua Jaffa com outros estudiosos. Sua vida era a tradição, o estudo de Deus e sua sagrada língua, mas uma coisa claramente começou a atormentá-lo. E a fonte de tal angústia envolvia um dos campos mais complexos da Torá: a gematria.

A gematria é o método ou a codificação pelo qual o Tanach foi escrito, isto é, a Torá, o Neviim e o Kethuvim, respectivamente a "Lei", os "Profetas" e os "Escritos". Os 39 livros que os católicos erroneamente chamaram de Velho Testamento, uma vez que não existia um novo.

Há um código nas escrituras divinas. Para decifrá-lo, Abraham sabia-o muito bem, se deveria saber que cada letra do alfabeto hebraico simboliza um número, cada palavra, outro número, cada versículo, mais um número, capí- 
tulos, números de novo e, ainda, haveria de se voltar sempre às escrituras em certas letras para entender qual foi o primeiro significado delas na Torá. As relações matemáticas são repletas de significações espirituais e isso maravilhava Abraham desde a infância.

Quando Abraham dava aulas às crianças haredim, facilmente as fazia entender a gematria por uns bons exemplos. Com todos os alunos a ajudá-lo em coro, ele primeiro escrevia da direita para a esquerda todas as letras do alfabeto hebraico.

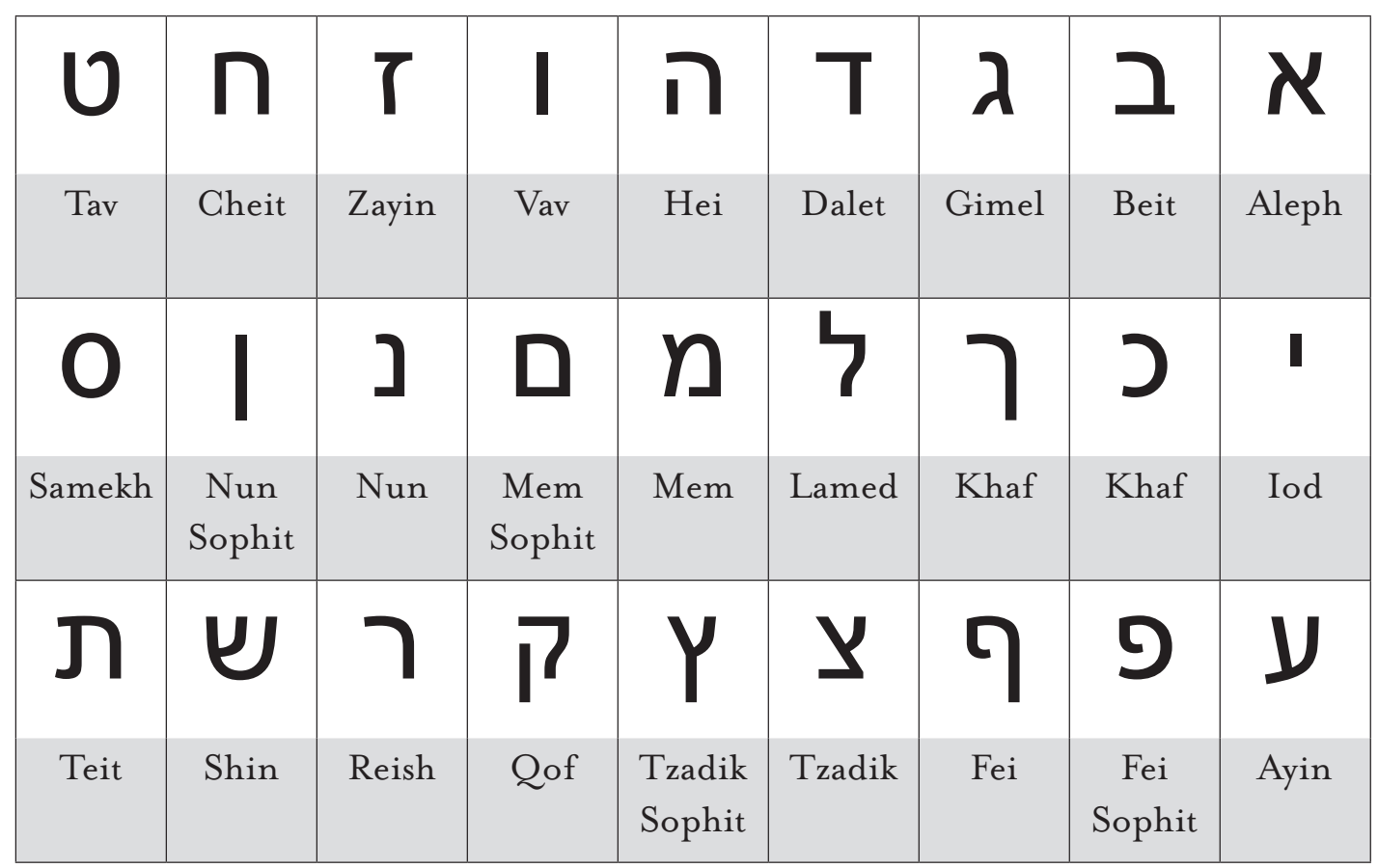

Abraham não admitia interrupções, sua primeira aula era sempre uma palestra, um monólogo... quase um dilúvio de informações. No entanto, ele pensava consigo: "O hebraico deve espantar... surpreender!" Assim, sua primeira lição era sempre mostrar por que Deus escolheu que a palavra davar significasse tanto "coisa" quanto "palavra". No meio do silêncio, ele lhes revelava num sussurro: "Porque foi quando Deus falou 'palavra' que TUDO, - isto é, tudo o que é coisa - se criou!”. As crianças tomavam um susto, mas essa injeção de adrenalina as fazia de certa maneira entender a magnitude das palavras do professor.

"Esta é a lição mais importante de nossas vidas... guardem-na bem. Davar é davar, ou seja, a palavra é coisa."

A segunda lição sempre era a palavra emet, que significava "verdade". 


\section{אמת}

A palavra emet é constituída da primeira (aleph), da intermediária (mem) e da última letra (tav) do alfabeto hebraico, justo como ele havia escrito na lousa negra. "A verdade é sempre completa, isto é, tem começo, meio e fim", logo dizia, "e não para por aí." Ele apontava as pernas das letras, dizendo: "Também a forma delas é importante para o nosso entendimento da língua sagrada". Todas as três letras tinham duas pernas: "A verdade se sustenta, ela nunca cai". E ele continuou: "Deus criou para tanto uma língua perfeita!”.

"E qual é o nome de Deus?"

A interrupção o tomou de ódio por um momento, pois se havia algo que o tirava do sério era isso. No entanto, era uma mera criança, que não teve educação nem para levantar antes a mão, pedindo autorização e obtendo para falar. Tudo soou fantástico para Abraham... nenhuma criança até então o havia feito, mas pelo fato de ter sido essa sua pergunta, isto é, "qual é o nome de Deus?", aquilo cravou em sua carne como nada o havia feito antes. E o espantou.

Depois de milésimos de segundos, para si mesmo, ele escreveu na lousa.

\section{יח}

Rapidamente, o menino respondeu: "Mas não há vogais, não há como ler".

Novamente a questão lhe encravava na carne. "Todos sabem que não há como se ler! Por que justo agora essa questão parece-me tão importante? As antigas escrituras não colocavam os pontos e riscos, que são as vogais, debaixo das letras, por isso não podíamos ler o verdadeiro nome de Deus. Mas será que era essa a verdade? Ou era apenas a primeira resposta conveniente?"

O silêncio aumentou de gravidade enquanto a cabeça de Abraham nadava em pensamentos, ainda quando outro homem de barba branca entrou na sala e começou a falar: "Bom, agora eu acho que é a minha vez".

Abraham apenas podia citar por cima algumas coisas em sua primeira aula, já que as próximas seriam dadas pelos mais velhos. Então, apenas dizia sobre o que era importante na língua hebraica em geral, mas que podia tomar décadas de vida: o significado da letra, sua forma, seu som, seu valor numérico no alfabeto e quando foi a primeira vez que a letra foi dita na Torá no radical de uma palavra. 
As outras aulas eram sempre ministradas por seu grande amigo, apesar de ser quarenta anos mais velho, Meir. Ele entrou rindo na sala de aula, descontraindo o ambiente sério e rígido que Abraham havia construído. "Todo ano a mesma coisa." Meir fazia sempre um espetáculo de mágica que Abraham nunca havia entendido o porquê.

$\mathrm{O}$ velho sequer hesitou em usar seu chapéu para o truque mágico. No entanto, sempre Abraham ia embora antes de ver no que daria aquele show.

Por causa daquela criança, Abraham entrou em casa sem dizer "boa-noite" à sua mulher ou a qualquer um de seus quatro filhos... foi direto ao seu escritório. Livros. "Deve haver alguma resposta que eu perdi por aqui." Logo, passou 24 horas apenas para catalogar em quais dos seus 2.I45 livros poderia ter a resposta. Sua mulher passava para ver como estava o marido, mas apenas podia olhar com orgulho as suas primeiras horas de estudos tão dedicados. No entanto, logo que ele perdeu o jantar, a companhia de sua cama e o café da manhã, percebeu que algo poderia estar muito errado.

Graças ao governo de Israel nenhum ortodoxo precisava trabalhar nem se alistar no exército, sua vida era estudar. Por isso, nada disso era anormal, mas seus filhos começaram a aparecer na porta no escritório e só ouviam o pai a dizer: "Deve haver algo por aqui... o nome de Deus... o nome de Deus..."

Um mês se passou. Depois de emagrecer um pouco, sua mulher começou a depositar um prato com comida na mesa em meio a tantos livros empilhados. Por muitas vezes, ela precisava abrir caminho entre as páginas para chegar perto do marido.

"Está por aqui... o nome de Deus... o nome de Deus está aqui..."

O pensamento se transformou em resmungo, em sussurro e logo em mantra...

Não tardou e...

Seis meses se passaram...

"Está por aqui... o nome de Deus... o nome de Deus está aqui..."

O cheiro no quarto já não estava suportável desde o primeiro mês, mas uma atmosfera de santidade ainda fazia todos da família se aproximarem, darem bom-dia e boa-noite ao pai, apesar dos olhos vermelhos não desviarem das letras marcadas por Deus nas tantas páginas e pergaminhos que esvaziaram das estantes para o chão.

Pessoas começaram a visitar o maior "estudioso de Deus" que ninguém jamais havia visto. Aos montes, alguns rezavam junto a Abraham, tocavam nele, em seus livros, em seu chapéu e até em suas tranças. Qualquer coisa para ter um pouco da santidade daquele homem com uma missão... uma missão divina. 
Passado um ano, as pessoas começaram a colocar bilhetes entre os blocos de pedra que formavam a parede de sua casa, instantaneamente era o novo muro das lamentações, o eastern wall. Todos vinham de manhã colocar os bilhetes, aproveitando assim o sol nascente. Não demorou para que os colegas de Abraham o ajudassem na catalogação de mais livros que ele pudesse ler que tivessem o segredo do nome de Deus. E até para que suas aulas fossem no jardim de casa, tendo o homem de dentro como inspiração constante.

"Está por aqui... o nome de Deus... o nome de Deus está aqui..."

Passados dois anos, sua casa se tornou um ponto turístico. Um ponto de passagem até para peregrinos na Terra Santa. Jovens e veteranos ortodoxos passavam pela casa de Abraham. Os homens deixavam livros e as mulheres, comida. Uma oração conjunta no fim da tarde era quase obrigatória.

"Está por aqui... o nome de Deus... o nome de Deus está aqui..."

"As quatro letras poderiam ser pronunciadas de quatro formas pela linguística hebraica: Iahveh, Iahvah, Iehvah, Iehveh. Isso se houvessem vogais, mas não havia. Então, teria apenas valor numérico-simbólico?”

Os seus rascunhos começaram já tantos que as finas folhas levitavam em seu escritório pela sua aura de concentração e movimentos rápidos, constantes e ventosos. Os números de cada letra, seu valor simbólico, a soma das letras de cada palavra, de cada versículo e o capítulo que capturou da Torá... tudo estava lá. Amigos, familiares e até desconhecidos iam até Abraham para ajudar a montar o que todos unanimemente chamavam de "A Grande Biblioteca de Abraham".

"Está aqui... há de haver um som..."

O homem santo despertado pela questão de uma criança não cessou durante cinco anos. E considerava a si próprio em uma missão santa, ainda que não pensasse em meio às suas leituras, já que não havia tal "meio". No entanto, quando completou sete anos de busca incessante pelo som do nome de Deus, ele desmaiou repentinamente.

As folhas pararam de voar.

Os peregrinos gritaram a catástrofe.

E Abraham, sem sentidos, foi levado por uma multidão ao hospital $\mathrm{Ha}$ dassah Ein Kerem, em Jerusalém.

O Estado de Israel parou.

O primeiro-ministro declarou feriado como se este fosse o começo de uma Paixão.

Demorou uma semana inteira para Abraham abrir os olhos.

Quando o homem santo acordou, não encontrou sua mulher ou filhos lhe esperando, mas Meir, seu amigo de longa data. Com um sorriso muito 
largo, quase escondido sob a barba, ele perguntou: "Como você está, meu velho amigo Abraham?"

"Oh..." A luz ainda atrapalhava a sua visão. "Não muito bem, Meir", o ar estava pesado e parecia que respirava pela primeira vez oxigênio. "Pesquisei todos os livros, manuscritos e inscrições que pude encontrar, fiz todas as operações matemáticas para encontrar o nome de Deus... o seu som e... nada." E ainda com grande esforço e um olhar desolado, completou: "Eu falhei em minha missão".

Abraham olhava a palma das mãos, que pareciam ainda mais vazias. Quando as cerrou, não conseguiu desviar seu olhar cabisbaixo e melancólico de seu amigo. Vergonha.

"Ha-ha-ha-ha-ha. Mas é claro que você não falhou em sua missão, meu caro amigo. Você ainda é jovem."

"Mas eu não sei O NOME!!!"

"Pois, então, eu te ensinarei."

Suas grossas sobrancelhas levantaram de perplexidade. E, pela primeira vez, o corpo de Abraham se movimentou, em uma tentativa súbita de levantar. Porém, até nisso falhou, pensou consigo.

"Então, vamos começar."

"Ken."

"Você sabe por que Deus escolheu que a palavra davar significasse tanto "coisa" quanto "palavra"? Porque foi quando Deus falou que TUDO se criou!"

"Mas essa é minha aula! Por que Meir está repetindo ela para mim?", pensava Abraham.

"E você sabe por que a palavra emet - que significa "verdade" - é constituída da primeira (aleph), da intermediária (mem) e da última letra (tav) do alfabeto hebraico, justo como está sempre escrito em nossa lousa negra? Porque a verdade é sempre completa, tem começo, meio e fim, e não para por aí..."

"Meir não está apenas me explicando minha aula, mas a está ministrando exatamente como eu faço! Entretanto, para isso, ele teria de ouvir a todas as minhas... não pode ser!"

"Também a forma delas é importante para o nosso entendimento da língua sagrada. Todas as três letras tem duas pernas: 'a verdade se sustenta, ela nunca cai'." E ele continuou: "Deus criou para tanto uma língua perfeita!".

"E eu nunca havia visto uma aula sequer de meu amigo", pensou amargurado Abraham. "Na verdade, qualquer espetáculo de mágica..."

Repentinamente, tirou o seu chapéu preto da cabeça grisalha.

"Sabe, Abraham, existem três etapas para a mágica acontecer. Primeiro, o mágico deve mostrar um objeto banal para a plateia." Meir então tinha um 
globo de vidro com o mapa mundi estampado nas mãos. "O segundo passo é fazê-lo desaparecer..." Das mãos de Meir a bola cai dentro do buraco do chapéu, ainda que não fizesse nenhum barulho ou nem movimentasse o fundo negro. Ele estica o braço na direção do outro e Abraham não vê nada no fundo do chapéu. "Então, meu caro, você tem de mostrar de volta aquele objeto banal que acabou de tornar mágico, mas não se engane! Não há como apenas mostrá-lo. Para tal, é preciso dizer as palavras mágicas...”

Alguns movimentos com as mãos, com o chapéu e...

"ABORAH CADABRAH!!!"

Tudo ficou envolto numa questão de microssegundos em uma fumaça negra, que leve e lentamente foi se dissipando. No entanto, nada disso distraiu a atenção de Abraham para a questão: "Por que a palavra mágica de Meir é na verdade a frase em hebraico: 'eu crio enquanto falo'? Isso não faz o menor sen..."

A fumaça se dissipou por completo.

E o entendimento relâmpago alcançou uma primeira vez Abraham.

O globo com o mapa mundi não apareceu nas mãos de Meir.

A mágica era muito mais profunda do que nunca se poderia imaginar.

Aquela pequena Terra apareceu.

Estava bem disposta na frente de Abraham.

Ela havia se criado aos seus olhos naquele instante.

E ele a olhava como se fosse sua primeira visão do mundo.

Aborah cadabrah, "eu crio enquanto falo".

"É claro que o nome de Deus não teria som..."

Depois de anos que nem se lembrava mais, Abraham finalmente sorriu.

"Afinal, Ele é o criador, não a criatura..."

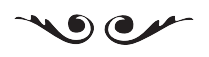

Paulo Abe - Graduando em Filosofia pela Universidade de São Paulo.

pauloaltro@hotmail.com 